\title{
RISK OF DUAL OCCURRENCE OF MONGOLISM IN SIBSHIPS
}

\author{
BY \\ J. M. BERG and B. H. KIRMAN \\ From the Fountain Hospital, London
}

(RECEIVED FOR PUBLICATION MAY 8, 1961)

A survey of sibships containing a mongol was undertaken to determine the risk to the mother of bearing a second mongol.

Opposing views have been expressed on the subject of familial incidence of mongolism. Benda (1947), Engler (1949) and Øster (1953a, 1956) have all stated or implied that the risk of bearing a second mongol child is no greater than the general risk of having a mongol. On the other hand, Penrose (1933) regarded the incidence of more than one mongol in a fraternity as greater than the random expectation. Böök and Reed (1950) stated that a woman who had borne a mongol had a 20 to 60 times greater chance of having another child similarly affected than if no mongol had been born in her family. Oliver (1950) concluded that the risk of a mother of a mongol having a second one was about 40 times that of any mother producing a child with mongolism. Carter, Hamerton, Polani, Gunalp and Weller (1960) referred to the experience at The Hospital for Sick Children, London, which has shown that 'the risk of parents having a second mongol child is almost certainly raised above the random risk, especially at the younger maternal ages'.

Despite these diverging views, there is a striking absence of reported extensive studies. This may be because such studies should be on a scale large enough to provide a substantial number of children born subsequent to a mongol. In the first place, because of the well-established tendency for mongols to be born to relatively old mothers, the likelihood of further children is reduced. Second, the fact of having had a mongol child may act as a deterrent to further child-bearing. Though no larger series on the incidence of mongolism among siblings born aitter a mongol appears to be available (the only comparably-sized series we were able to find was that of Øster (1956), which contained 343 siblings born after a mongol, among whom there were four further instances of mongolism), we realize that our numbers are not great. We record our findings, however, with the hope that similar data will be collected from other sources, and that sufficient will become available to substantiate or modify our tentative conclusions.

\section{Material and Methods}

The records of sibships containing a mongol were studied in two mental deficiency institutions (the Fountain Hospital, London and St. Lawrence's Hospital, Surrey), and the four district offices of the London County Council which together contain information about mongols in the whole London area. The records were compiled in the first instance by social workers who routinely visited the homes and completed a social report and history, paying particular attention to the presence of other retarded children.

The records examined at the Fountain Hospital were those of all mongols admitted from 1947 to 1959 inclusive; at St. Lawrence's Hospital, those of all mongols in the hospital at the time of the study (May 1959) and at the four London County Council district offices, those of all mongols known to the London County Council to be living at home in London at the time (April 1959). Occasionally, records of a particular sibship were present in more than one of these sources; such a sibship was counted once only. The cases studied are thus a random series of both institutionalized mongols and mongols living at home.

In each instance, a note was made of the maternal age at the birth of the mongol child who was the propositus, and at that of all known subsequent live births. The occurrence of further children with mongolism among the subsequent live births was noted. Where a mongol was a member of a twin pair, the other member of the pair was not counted as a subsequent birth. In all cases, the diagnosis of mongolism was made by medical officers familiar with the condition.

In the case of the four London County Council district offices, the child-bearing histories of the 
mothers of the mongol propositi were almost always up to date at the time of the study. However, this was not so in the case of the mothers of the St. Lawrence's Hospital series and 140 of the mothers of the Fountain Hospital series. An attempt was therefore made to bring the childbearing histories of the mothers of the propositi in these two hospitals up to date. This was done by sending out a questionnaire (Appendix A), accompanied by a brief explanatory letter, to all 96 mothers of the St. Lawrence's Hospital series and the 140 mothers of the Fountain Hospital series. Replies were received from $68(71 \%)$ of the former and $91(65 \%)$ of the latter. In this way an additional 29 younger siblings of the mongol propositi were traced, none of whom was a mongol.

\section{Results and Discussion}

Records of the child-bearing histories, beginning with the birth of the mongol propositus, were obtained from the above sources in a total of 778 mothers. Information on the child-bearing histories of the mothers was up to date at the time of the study in $80 \%$ of the Fountain Hospital series, $71 \%$ of the St. Lawrence's Hospital series and practically $100 \%$ of the London County Council series, and thus in $90 \%$ of the 778 mothers. The results are shown in Table 1.

Bearing in mind that data about subsequent births were not known in some $10 \%$ of the mothers, the Table indicates that about two-thirds of the mothers of mongols do not have further children.

The incidence of mongolism was found by Carter and MacCarthy (1951) to be one in 666 maternities in London and the Home Counties, a figure close to that of other surveys of populations of European origin which have indicated an incidence of mongolism at birth of the order of one in 700 (Penrose, 1954). In our data (Table 1), there were seven second occurrences of mongolism among 367 children born after a mongol (one in 52), an incidence some 13 times greater than that in the general population at birth. However, as the mothers of mongols are, of course, older at the birth of subsequent children, and as the incidence of mongolism rises with maternal age, significant comparisons must take account of the effects of maternal age. This is done in Table 2, using Carter and MacCarthy's (1951) findings of the incidence of mongolism at different maternal ages for comparative purposes.

Thus, taking account of maternal ages, our data indicate that the incidence of mongolism among younger siblings of mongols is 3.7 times greater (seven) than the expected incidence $(1 \cdot 90)$ if there had been no increased risk of having a second mongol. The significance of these findings can be best tested by means of the Poisson distribution which tests the probability of occurrence of rare events. Using this distribution, the probability of seven or more further mongol children occurring in the present series of younger siblings of mongols, among whom the expected incidence is $1 \cdot 9$, is $0 \cdot 003$. It would be very useful, in guiding mothers of mongols on the question of further child-bearing, if the general figure for the increased risk of bearing a second mongol could be subdivided into figures of the risk at various maternal ages. Our data are, unfortunately, too small for this purpose. However, on dividing the mothers into the two maternal age groups of under 40 years and 40 years and over, the data suggest a greater increased risk in the younger group (Table 3). This is in keeping with the experience at The Hospital for Sick Children referred to above (Carter et al., 1960). Penrose (1951) noted a tendency to a lower maternal age in familial cases of mongolism. An explanation for this may be that some of these cases are due to a transmissible chromosome abnormality (Polani, Briggs, Ford, Clarke and Berg, 1960; Carter et al., 1960). At least part of the additional risk of bearing a further child with mongolism in mothers

TABLE 1

CHILD-BEARING HISTORIES OF 778 MOTHERS COMMENCING WITH THE BIRTH OF A MONGOL

\begin{tabular}{|c|c|c|c|c|c|c|c|c|c|c|}
\hline \multirow[t]{2}{*}{ Source } & \multirow{2}{*}{$\begin{array}{c}\text { No. } \\
\text { of } \\
\text { Mothers }\end{array}$} & \multicolumn{2}{|c|}{$\begin{array}{c}\text { Sex of } \\
\text { Mongol } \\
\text { Propositus }\end{array}$} & \multirow{2}{*}{$\begin{array}{l}\text { No. of } \\
\text { Mothers } \\
\text { With Known } \\
\text { Subsequent } \\
\text { Live-births }\end{array}$} & \multirow{2}{*}{$\begin{array}{c}\text { Mothers } \\
\text { Mith Known } \\
\text { Wubsequent } \\
\text { Live-births }\end{array}$} & \multicolumn{3}{|c|}{$\begin{array}{c}\text { No. of } \\
\text { Subsequent } \\
\text { Live-births }\end{array}$} & \multicolumn{2}{|c|}{$\begin{array}{l}\text { No. of Mongols } \\
\text { Among Subse- } \\
\text { quent Live-births }\end{array}$} \\
\hline & & Female & Male & & & Total & Female & Male & Female & Male \\
\hline $\begin{array}{l}\text { Fountain Hospital } \\
\text { St. Lawrence's Hospital } \\
\text { L.C.C. District A } \\
\text { L.C.C. District B } \\
\text { L.C.C. District C } \\
\text { L.C.C. District D }\end{array}$ & $\begin{array}{r}244 \\
96 \\
113 \\
91 \\
114 \\
120\end{array}$ & $\begin{array}{r}106 \\
48 \\
60 \\
40 \\
67 \\
65\end{array}$ & $\begin{array}{r}138 \\
48 \\
53 \\
51 \\
47 \\
55\end{array}$ & $\begin{array}{l}85 \\
28 \\
30 \\
27 \\
35 \\
30\end{array}$ & $\begin{array}{l}35 \\
29 \\
27 \\
30 \\
31 \\
25\end{array}$ & $\begin{array}{r}141 \\
41 \\
50 \\
46 \\
47 \\
42\end{array}$ & $\begin{array}{l}58 \\
24 \\
25 \\
18 \\
22 \\
19\end{array}$ & $\begin{array}{l}83 \\
17 \\
25 \\
28 \\
25 \\
23\end{array}$ & $\frac{1}{1}$ & $\frac{2}{1}$ \\
\hline Totals & 778 & 386 & 392 & 235 & 30 & 367 & 166 & 201 & 3 & 4 \\
\hline
\end{tabular}


TABLE 2

INCIDENCE OF MONGOLISM, IN CHILDREN OF MOTHERS WHO HAVE PREVIOUSLY HAD A MONGOL CHILD, IN RELATION TO MATERNAL AGE

\begin{tabular}{|c|c|c|c|c|}
\hline $\begin{array}{l}\text { Maternal Age at Birth } \\
\text { of Subsequent Child } \\
\text { (years) }\end{array}$ & $\begin{array}{c}\text { No. of } \\
\text { Subsequent } \\
\text { Live-born Children }\end{array}$ & $\begin{array}{c}\text { Incidence of Mongolism } \\
\text { per 1,000 Births } \\
\text { (Carter and MacCarthy, } \\
\text { 1951) }\end{array}$ & $\begin{array}{l}\text { Expected Incidence in } \\
\text { Subsequent Births if Risk } \\
\text { is Not Increased }\end{array}$ & $\begin{array}{l}\text { Actual Incidence } \\
\text { in Subsequent } \\
\text { Children }\end{array}$ \\
\hline \multirow[t]{2}{*}{$\begin{array}{r}-19 \\
20- \\
25- \\
30- \\
35- \\
40- \\
45-\end{array}$} & $\begin{array}{r}0 \\
26 \\
59 \\
99 \\
102 \\
65 \\
16\end{array}$ & $\begin{array}{r}0 \cdot 00 \\
0 \cdot 28 \\
0 \cdot 29 \\
1 \cdot 72 \\
3 \cdot 52 \\
14 \cdot 18 \\
26 \cdot 32\end{array}$ & $\begin{array}{l}0 \cdot 00 \\
0 \cdot 01 \\
0 \cdot 02 \\
0 \cdot 17 \\
0 \cdot 36 \\
0 \cdot 92 \\
0 \cdot 42\end{array}$ & $\begin{array}{l}0 \\
1 \\
0 \\
0 \\
3 \\
3 \\
0\end{array}$ \\
\hline & 367 & & $1 \cdot 90$ & 7 \\
\hline
\end{tabular}

TABLE 3

INCREASED RISK OF HAVING A SECOND CHILD WITH MONGOLISM

\begin{tabular}{|c|c|c|c|c|}
\hline $\begin{array}{l}\text { Maternal Age at Birth } \\
\text { of Subsequent Child } \\
\text { (years) }\end{array}$ & $\begin{array}{l}\text { No. of Live Births } \\
\text { After Birth of } \\
\text { Mongol }\end{array}$ & $\begin{array}{l}\text { Expected Incidence of } \\
\text { Mongolism in Subsequent } \\
\text { Births if Risk is Not } \\
\text { Increased }\end{array}$ & $\begin{array}{l}\text { Actual Incidence } \\
\text { of Mongolism in } \\
\text { Subsequent Births }\end{array}$ & Risk Increased By \\
\hline $\begin{array}{r}-40 \\
40-\end{array}$ & $\begin{array}{r}286 \\
81\end{array}$ & $\begin{array}{l}0 \cdot 56 \\
1 \cdot 34\end{array}$ & $\begin{array}{l}4 \\
3\end{array}$ & $\begin{array}{l}7 \cdot 1 \times \\
2 \cdot 2 \times\end{array}$ \\
\hline Totals .. & 367 & $1 \cdot 90$ & 7 & $3 \cdot 7 \times$ \\
\hline
\end{tabular}

who have previously had one affected child may be due to such transmissible defects as distinct from the usual anomaly of an additional separate somatic chromosome.

Mongolism and Twinning. Table 4 shows the association of twinning with mongolism among 778 mongol births. The birth was one of twins in nine instances, an incidence of twinning of one in 86 births.

By comparison, the number of twin maternities registered in England and Wales in 1955 was 8,437 in a total of all maternities of 675,026 or one in 80 (Registrar-General, 1957). The proportion of twins actually born alive was slightly less (one in $41 \cdot 7$ ), this difference from the one in 40.5 expected representing the excess of twin stillbirths over single pregnancy stillbirths. Thus the incidence of twinning in mothers bearing a mongol appears to be practically identical to that among mothers in general. On the basis of Carter and MacCarthy's (1951) finding of one mongol per 666 maternities, mongolism would therefore be associated with twinning once in approximately 57,000 births in this country.

Most of the reported cases of twinning in association with mongolism have been of twin pairs discordant for mongolism. Øster (1953b) found 97 recorded instances of mongolism in one (79) or both (18) twins. Concordance for mongolism in twins is relatively rarer than this proportion suggests (79:18), as such pairs are more likely to be reported than discordant ones. The proportion of discordant to concordant pairs in our series was eight to one. Unfortunately, it was not possible to establish ovularity in our sets of twins. However, as Øster (1953b) found in his analysis of published reports,

TABLE 4

ASSOCIATION OF TWINNING WITH MONGOLISM AMONG 778 MONGOL BIRTHS

\begin{tabular}{|c|c|c|c|c|}
\hline \multirow{2}{*}{$\begin{array}{c}\text { Maternal Age } \\
\text { at Birth of } \\
\text { First Mongol } \\
\text { (years) }\end{array}$} & \multirow{2}{*}{$\begin{array}{l}\text { No. of } \\
\text { Cases }\end{array}$} & \multirow{2}{*}{$\begin{array}{c}\text { No. } \\
\text { Associated } \\
\text { With } \\
\text { Twinning }\end{array}$} & \multicolumn{2}{|c|}{ Other Twin } \\
\hline & & & $C$ or $D^{*}$ & Sex $\dagger$ \\
\hline $\begin{array}{r}-19 \\
20- \\
25-\end{array}$ & $\begin{array}{r}12 \\
81 \\
101\end{array}$ & $\begin{array}{l}\mathbf{0} \\
\mathbf{0} \\
\mathbf{0}\end{array}$ & $\bar{z}$ & 二 \\
\hline $30-$ & 109 & 3 & D & SS (F) \\
\hline $35-$ & 222 & 2 & D & $\begin{array}{l}\text { SS (F) } \\
\text { SS (F) }\end{array}$ \\
\hline $40-$ & 206 & 4 & $\begin{array}{l}\mathrm{D} \\
\mathbf{D} \\
\mathbf{D}\end{array}$ & $\begin{array}{l}\text { SS (F) } \\
\text { OS (F) }\end{array}$ \\
\hline $45-$ & 47 & 0 & - & - \\
\hline Totals & 778 & 9 & $1 \mathrm{C} ; 8 \mathrm{D}$ & $6 \mathrm{SS} ; 3$ OS \\
\hline
\end{tabular}

* $\mathbf{C}=$ concordant for mongolism; $\mathbf{D}=$ discordant for mongolism + SS = same sex; OS = opposite sex. 
concordance occurred only in a same-sex pair, whereas discordance was noted in both same- and opposite-sex pairs.

\section{Summary}

The risk of another mongol being born to a mother who had already had such a child was investigated. Records from London and Surrey of 778 sibships containing a mongol were studied, the propositi consisting both of subjects living at home and those in institutions. Two hundred and thirtyfive mothers of 778 mongols (30\%) had known subsequent live-births, a total of 367 in all, among whom were seven second cases of mongolism (one in 52). Analysis of the 367 subsequent births, in relation to maternal age, showed a 3.7 times greater incidence of mongolism than the incidence expected if there had been no increased risk of having a second mongol. This increased incidence is statistically significant.

It is tentatively concluded that the general risk of having another mongol is increased nearly four-fold once a mother has had such a child. If similar data were collected from other sources, this conclusion could be substantiated or modified, and sufficient information would become available to subdivide the general figure for the increased risk of bearing a second mongol into risk figures at various maternal ages.

Nine of the 778 mongols were products of twin birth (one in 86) suggesting, on the basis of an incidence of mongolism of one in 666 maternities, an association of twinning with mongolism, in this country, once in about 57,000 births. Of the nine twin pairs, one was concordant for mongolism (a same-sex pair) and the other eight discordant (both same- and opposite-sex pairs).

We are grateful to Dr. C. W. J. Ingham for permission to examine the records of mongols living at home in London, and to Dr. Doreen Firmin for similar permission with regard to mongols in St. Lawrence's Hospital; to Miss N. E. S. Brian, Miss A. M. Joseph, Mrs. G. Paterson and Miss G. Russell for putting the records in their respective London County Council District Offices at our disposal, and to Dr. B. W. Richards for assistance with the St. Lawrence's Hospital records; to Miss M. F. Craib for help with collection of the data; to Dr. W. W. Holland for guidance with statistical problems; and to Dr. C. O. Carter, as well as our colleagues at the Fountain Hospital, for helpful comments.

\section{REFERENCES}

Benda, C. E. (1947). Mongolism and Cretinism, p. 251. Heinemann,

Bö̌k, J. A. and Reed, S. C. (1950). Empiric risk figures in mongolism. J. Amer. med. Ass., 143, 730 . Carter, C. and MacCarthy, D. (1951). Incidence of mongolism and
its diagnosis in the newborn. Brit. J. prev. soc. Med., 5,83 .

Carter, C. O., Hamerton, J. L., Polani, P. E., Gunalp, A. and Weller, S. D. V. (1960). Chromosome translocation as a cause of familial mongolism. Lancet, 2, 678.
Engler, M. (1949). Mongolism (Peristatic Amentia), p. 131. Wright, Bristol.

Oliver, C. P. (1950). Mongolism: multiple occurrence in sibships. Eugen. News, 35, 35.

Øster, J. (1953a). Mongolism, p. 131. Danish Science Press, Copenhagen.

(1953b). Ibid., pp. 123-8.

(1956). The causes of mongolism. Dan. med. Bull., 3, 158.

Penrose, L. S. (1933). Mental Defect, p. 107. Sidgwick and Jackson, London.

(1951). Maternal age in familial mongolism. J. ment. Sci.,

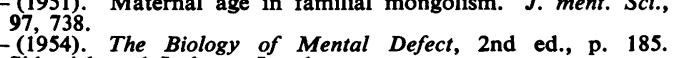
Sidgwick and Jackson, London.

Polani, P. E., Briggs, J. H., Ford, C. E., Clarke, C. M. and Berg, J. M. (1960). A mongol girl with 46 chromosomes. Lancet, 1, 721.

Registrar-General (1957). Statistical Review of England and Wales for the Year 1955, Part 2, p. 150 . London.

\section{APPENDIX}

Questionnaire sent to mothers of mongol propositi whose available child-bearing histories were not up to date.

$$
\text { No. ........ }
$$

I. Mother's date of birth ..............

2. Name, date of birth and sex of child with mongolism

3. Were any children born after the child with mongolism? (State Yes or No) $\ldots . . .$. .

4. If yes, please state names, dates of birth and sex of all these children:

5. Are all the children born after the child with mongolism healthy and normal? (State Yes or No)

6. If no, please state what each one suffers from, particularly mentioning if any of them is also a case of mongolism: 